\title{
Editorial: Analytic or Continental? The Case of Roger Scruton
}

Analytical philosophy, as practiced in the English speaking world, is rightly esteemed for its clarity and rigour. It often takes the forms and methods of the natural sciences, or what it takes to be those forms and methods, as ideal. It tends to take as its subject matter issues which lend themselves to technical or semi-technical treatment, which makes it seem remote from anything that might be of interest to the non-philosopher. Philosophy emanating from the European mainland (and known at one time slightly disparagingly as 'continental'), by contrast, is characteristically written in a far looser style. As if in compensation, it can usually be seen to be dealing with topics which have some relation to general human concerns. Unfortunately, the looser style may well be a disadvantage here as continental philosophy can, in the view of its analytic critics anyway, lose itself in oracularity and obscurity, and at times in irrationality.

In the heyday of British analytical philosophy there were some cross-channel attempts to bring the two traditions together. The participants may have enjoyed themselves, but overall they were not a success. The divisions they were seeking to remedy have become more and more entrenched. Mutual incomprehension has deepened, and so has mutual suspicion, which is a pity. Clarity is essential, but not enough. Questions relating to how we should live and feel in a general sense should be of central philosophical import, but they need to be dealt with in clear and generally intelligible terms, free from jargon and obfuscation.

It is against this background that Sir Roger Scruton is an important thinker. Like many of his continental colleagues, he does deal with key questions in aesthetics, in religion and in politics. He writes on the environment, on a sense of home and the yearning for it, and on the significance of music and architecture and literature - all aspects of what go to constitute our Lebenswelt, the world in which we live and move and have our being as human persons, but which are on the margins in the analytic schools of philosophy. In his writing Scruton is never less than clear. He never betrays the analytical tradition in which he was formed. Like many of his AngloAmerican colleagues he is moreover, though perhaps paradoxically, steeped in the work of Kant and Wittgenstein. 


\section{Editorial}

In his own work Scruton thus bridges the analytic-continental divide, while at the same time covering a very wide range of key issues, philosophical and human, in a manner never less than engaged and intellectually challenging. In his recent work he is striking and original on the need for the sacred, on love of home, which he calls oikophilia, on forgiveness and the music of Wagner, and even on the significance of wine. We hope in this issue of Philosophy to give some idea of the interest and scope of his philosophy, and also of the relationship between that and his considerable literary output another aspect of his work with continental rather than analytical associations.

Sir Roger Scruton has been honoured academically and in other ways, both in Britain and the United States, and in countries of Eastern Europe where he played a significant role with the dissident underground during the era of the Soviet dictatorships. But, as is well-known, he is also a figure who has attracted controversy and, at times, venom. We have no view here on the detail of any of that, save to say that some of those who attack him clearly have not read him, nor do they have sense of the possibility, the necessity even, of reasonable disagreement. Something of the situation in which we are intellectually to-day has been well summed up by the distinguished French philosopher Chantal Delsol: 'At present when autocratic regimes are fading and democracies are spreading, majority opinion will, as it were, take the autocrat's place by imposing a way of thinking on the individual. While perhaps for the first time in history it is possible to think anything, one can see that almost everyone is singing the same tune.' She is, of course, echoing de Tocqueville, but what he only foretold, she and we know, at least as far as a large segment of the intellectual and bureaucratic world goes. What we hope to show in this issue of Philosophy is how, at the age of 75 , Scruton emphatically demonstrates that it is possible to think philosophically in the twenty-first century, while singing one's own tune, and to do so rigorously and consistently. 